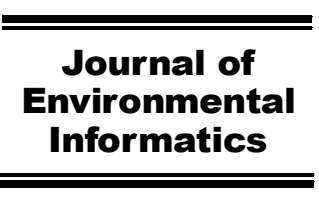

www.iseis.org/jei

\title{
Geocode-Based Aquatic Habitats in Hierarchical System of the Yellow River Basin
}

\author{
Y. C. Wang ${ }^{1}$, X. W. Gao ${ }^{1}$, T. J. Li ${ }^{2}$, Y. Yue ${ }^{3}$, H. Q. Fang ${ }^{4}$, J. R. Ni ${ }^{1}{ }^{*}$ \\ ${ }^{l}$ Department of Environmental Engineering, Peking University; Key Laboratory of Water and Sediment Sciences, Ministry of Education, Beijing \\ 100871, China \\ ${ }^{2}$ State Key Laboratory of Plateau Ecology and Agriculture, Qinghai University, Xining 810016, Qinghai, China \\ ${ }^{3}$ School of Water Resources and Hydropower Engineering, Wuhan University, Wuhan 430072, China \\ ${ }^{4}$ School of Mathematical Sciences, Peking University, Beijing 100871, China
}

Received 24 January 2018; revised 14 March 2018; accepted 5 April 2018; published online 13 June 2018

\begin{abstract}
Riverine systems are primary habitats for aquatic species. Great efforts have been made to understand interaction between aquatic organism and various environmental factors in specific reaches of a river, yet little was known about how to identify habitats in river networks. In this paper, a comprehensive approach was proposed for identification of aquatic habitats in hierarchical river systems in terms of integrated geocodes synthesized through over-layer of multiple factors such as geologic periods, climatic conditions, water sources, geomorphic characteristics and river patterns. Using this approach in the Yellow River Basin over an area of $758,600 \mathrm{~km}^{2}$, six groups of aquatic habitats were classified by clustering of 85 geocodes, and 313 sub-habitats were further identified by considering both surface composition (e.g., lithological features and soil texture) and topographic property (e.g., elevation and slope) in the loess geomorphic regions. Consequently, the contribution of the headwater streams to diversity of aquatic habitats among rivers and mid-sized rivers to the diversity within a river has been revealed by coupling of the geocode-based habitats and the river networks. The present study is of significance to efficient capture of habitat diversity and better understanding of biodiversity in rivers of different stream orders.
\end{abstract}

Keywords: geocodes, habitats, hierarchical river system, identification, Yellow River

\section{Introduction}

River systems are of great significance not only to transportation of water (Huang and Loucks, 2000; Milly et al., 2005), sediment (Huang, 1998; Syvitski et al., 2005; Qin et al., 2007; Li, et al., 2008), and other associated materials ( $\mathrm{Li}$, et al., 2009; Regnier et al., 2013) from land to ocean, but also to providing habitats for aquatic species (Benda et al., 2004). River networks are hierarchical systems consisting of rivers of different orders. The degree of stream branching can be characterized by different stream-ordering rules (Horton, 1945; Strahler, 1952, 1957; Shreve, 1966; Huang, et al., 2006; Li, et al., 2010; Lv, et al., 2010), in which Horton and Strahler stream-ordering schemes are most commonly used. The structure properties of river networks have been long concerned from mathematic, hydrological, and geomorphological perspectives since 1940s. It has been found that the topological parameters (e.g., number of rivers and bifurcation ratio) and morphological parameters (e.g., river length, basin area) of rivers with different stream-orders follow some geometric laws (Horton, 1945), along which, self-similarity in natural

${ }^{*}$ Corresponding author. Tel.: (+86) 10-62751185; fax: (+86)10-62751480. E-mail address: jinrenni@pku.edu.cn (J. R. Ni).

ISSN: $1726-2135$ print/1684-8799 online

(C) 2018 ISEIS All rights reserved. doi:10.3808/jei.201800386 river net- works has also been confirmed (Zanardo et al., 2013; Fan et al., 2017a; Wang et al., 2018). Moreover, the fractal dimension was introduced to describe the dendritic nature of river networks (Veltri et al., 1996; Zhang et al., 2015). More recently, interactions between hierarchical river networks and natural processes including climate change (Zanardo et al., 2013), water and sediment balance (He et al., 2012; Czuba and Foufoula-Georgiou, 2015), geomorphic evolution (Lave, 2015), greenhouse gases emissions (Hotchkiss et al., 2015), and biological communities (Campbell and Mcintosh, 2017) were investigated. In particular, aquatic habitat conditions (Baattrup-Pedersen et al., 2017), and distribution (Ceola et al., 2014), diversity (Rice, 2017), and dispersal (Swan and Brown, 2017) of stream communities all appeared to have remarkable correspondence with structure properties of river networks. Since the hierarchical structure of river networks causes substantial ecological responses, it is essential to take structure properties of river networks into account when depicting riverine habitat characteristics.

Great efforts have been made to identify riverine habitats in terms of physical attributes. Climate factors (He, 2017), hydraulic parameters (Buffagni et al., 2000), geomorphic factors (Inglis et al., 2008), land cover characteristics (Ardli and Wolff, 2009), and channel morphological metrics (Whited et al., 2013) have been selected for habitat descriptions. With the increasing human disturbance on rivers, habitat quality evalu- 
ation systems for urban rivers (Boitsidis et al., 2006; Zeng et al., 2007) as well as rivers impacted by reservoirs (Ma et al., 2014) were also investigated. $\mathrm{Ni}$ and Gao $(2011 \mathrm{a}, \mathrm{b})$ proposed a comprehensive riverine habitat identification system which combined information of geologic period, climatic condition, water sources, and geomorphic features. Similarly, Mckenna et al. (2015) characterized riverine habitat conditions based on a spatially universal framework composed with multi-dimension variables including climate, stream flow, stream geometry, geology, land cover, and water temperature.

Although aquatic habitats and river networks in various catchments are separately investigated in previous studies, less efforts have been made to describe habitats in the context of hierarchical river systems. In this paper, an integrated framework (Figure 1) was established for identification of aquatic habitats in terms of stream orders, which could well describe hierarchical characteristics of riverine habitats originally defined with geocodes synthesized through over-layer of multiple factors. Consequently, riverine habitat diversities corresponding to different stream-orders could be identified, which is helpful to accurate capture of biodiversity patterns and deeper understanding of community assembly mechanisms.

\section{Study Area}

The Yellow River, the second longest river in China, has a total river length of 5,464 km. Yellow River originates from Qinghai-Tibet Plateau, flows through seven provinces and two autonomous regions of China, finally injects into Bohai Sea. The Yellow River Basin is distributed in $95^{\circ} 53^{\prime} \mathrm{E} \sim 119^{\circ} 05^{\prime} \mathrm{E}$, $32^{\circ} 10^{\prime} \mathrm{N} \sim 41^{\circ} 50^{\prime} \mathrm{N}$, with a total area of $758,600 \mathrm{~km}^{2}$ (Editorial Committee of Encyclopedia of Rivers and Lakes in China, 2014). The Yellow River Basin shows diverse climate patterns, including humid climate in the southeastern area, the semiarid climate in the central part, and the arid climate in the northwestern region. It flows through one of the largest and thickest loess deposits in the world where soil erosion is severe (Ni et al., 2014), and has the largest average annual sediment yield $\left(1.6 \times 10^{12} \mathrm{~kg} / \mathrm{yr}\right.$ during $\left.1919 \sim 1960\right)$ and sediment concentration $\left(35 \mathrm{~kg} / \mathrm{m}^{2}\right.$ during $\left.1919 \sim 1960\right)$ in the world (Editorial Committee of Encyclopedia of Rivers and Lakes in China, 2014). Heterogeneous source of water and sediment is another remarkable characteristic of Yellow River (He et al., 2009). The middle reaches of Yellow River located between Hekouzhen and Sanmenxia are the major source areas of sediment, occupying $89.1 \%$ of the total sediment yield and $28 \%$ of the total runoff. The upstream reaches of Yellow River located above Hekouzhen and Sanmenxia account $62 \%$ of the total runoff, and only $8.6 \%$ of the total sediment yield (Editorial Committee of Encyclopedia of Rivers and Lakes in China, 2014).

\section{Methodology}

\subsection{Extraction of Drainage Networks}

Drainage networks were extracted from the $30 \mathrm{~m}$ resolu- tion Aster GDEM (Available at http://reverb.echo.nasa.gov/ reverb/) by a high efficient method based on a sized-balanced binary search tree (Bai et al., 2015). The extraction procedure comprises five steps: (1) pretreatment to fill local depressions; (2) determination of flow directions; (3) accumulation of upslope areas; (4) identification of drainage channels based on threshold values of critical source area and local slope, and (5) vectorization of geographic features. In this study, we set the threshold values of critical source area (number of grid cells) and local slope as 20 and 0.01 , respectively.

\subsection{River System Hierarchy}

The Strahler stream-ordering scheme (Strahler, 1952, 1957) was used, in which first-order rivers are headwaters without bifurcation. When there is a confluence, the streamorder of downstream rivers obeys the following rules:

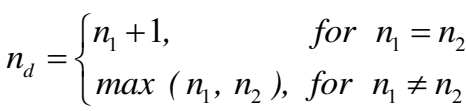

where $n_{d}$ is the stream order of the downstream river, and $n_{l}$ and $n_{2}$ are the respective stream orders of the upstream rivers at the bifurcation.
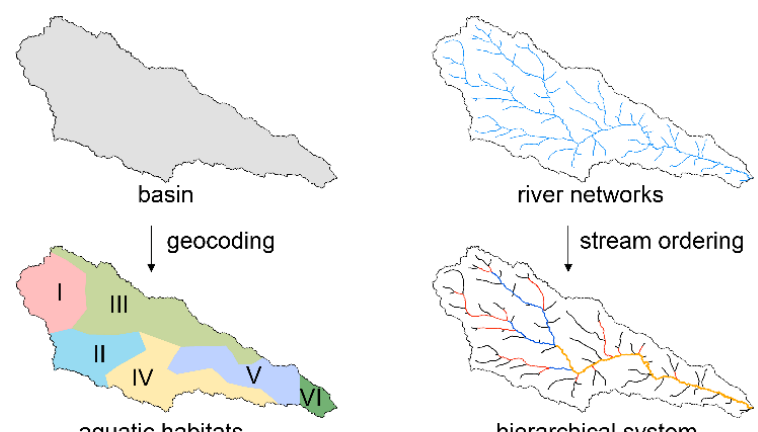

aquatic habitats

hierarchical system
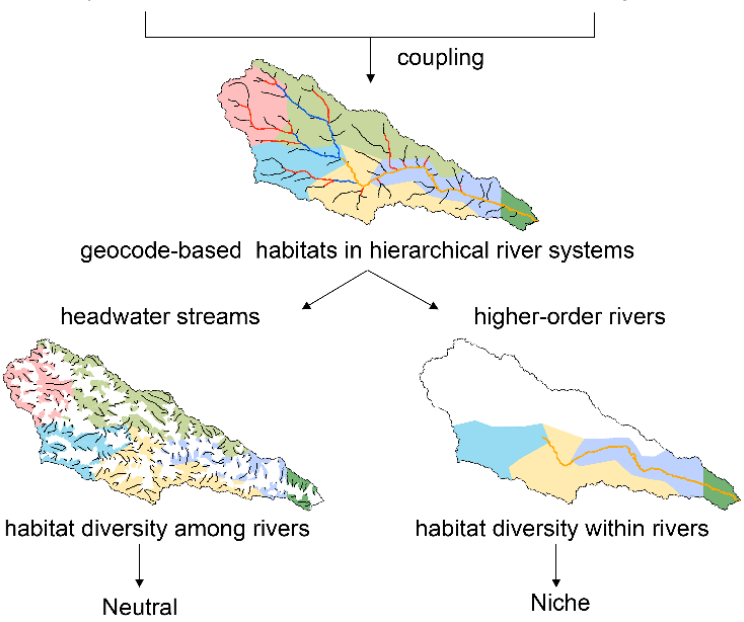

Figure 1. Framework for geocode-based aquatic habitats identification in river networks. 


\subsection{Integrated Geocodes System Coupled with Stream Order}

With the spirit of Ni and Gao (2011a, b; An et al., 2016; Xin et al., 2017; Zhang et al., 2017), we proposed a comprehensive approach to identify the aquatic habitats in the hierarchical river system in terms of an integrated geocodes system for all stream orders (Table 1). The geocodes were synthesized through overlay of environmental factors including geologic period, climatic condition, water source, geomorphic characteristics and river pattern.

\subsubsection{Geologic Period}

The geological history of rivers records formation, development, and evolution of rivers. Most modern rivers were generated in Quaternary period when large scale of glacier developed, and the glacier meltwater might provide a new type of water source for rivers. In the Yellow River Basin, arid and cold climate resulted in deposition of loess sediment. Freshwater organisms were spatially divided, and distributed scope of the cold-water species expanded during this period.

\subsubsection{Climatic Condition}

From a geospatial perspective, rivers in different regions correspond to different climate conditions dominated by precipitation and temperature. Hence, rivers could be spatially classified in terms of tropic and subtropic climate, temperate climate, frigid climate, and plateau climate (Liu, 2010; Xin et al., 2018). In the Yellow River Basin, the temperate climate could be further subdivided into monsoon climate of medium latitudes and temperate continental climate.

\subsubsection{Water Source}

Water sources of rivers are also closely related to hydrological characteristics (e.g., flow regime) of rivers. Rivers in temperate climate regions may have multiple water sources including glacial permafrost, precipitation, and groundwater. However, rivers supplied by glacial permafrost tend to have a spring flood since thaw out of glacier often happens in spring, while those supplied by precipitation mostly have a flood period in summer. Groundwater would be major water sources for inland rivers distributed in arid regions or rivers in areas with high permeability (e.g., loess landform regions). However, rivers in plateau climate regions are mainly supplied by snowmelt of glacier or lakes and swamps.

\subsubsection{Geomorphic Characteristics}

Modern rivers may flow through areas with fluvial, karst, loess, and glacial permafrost landforms (Tian, 2009). The surface soil texture and lithologic composition would influence the properties of streambed sediment and the salinity of water body. On the other hand, topographic condition is the main driver to shape the river pattern.

Rivers flowing through loess landforms are mainly distributed in arid and semi-arid regions, and often correspond to extensive groundwater system. Considering loess sediments are product of weathering and freeze-thaw action, stream-bed sediments of these rivers are fine-grained with high porosity. Moreover, rivers flowing through glacial permafrost regions are mostly covered with moraine, and the stream-bed sediments are composed of glacial debris. Exchange of surface runoff and groundwater flow are weak due to barrier action of permafrost.

\subsubsection{River Pattern}

Rivers are conventionally classified into straight, meandering, braided, and anastomosed patterns from their plane views. The straight river is not stable and mainly distributed in restricted valley regions, while meandering river is of idealized pattern for evolution of a stable channel. However, braided and anastomosed rivers with multiple-channels are often characterized with frequent change of flow courses due to lower longitudinal gradient, higher sediment load, and poorer resistance of bank materials.

\subsection{Identification of Aquatic Habitats}

In the established integrated geocode system, the environmental factors could largely determine aquatic habitats in rivers. For a hierarchical analysis, each of the factors could be further defined by several sub-factors with quantitative gradation. Hence, representative riverine habitats were firstly identified in terms of geocodes generated by overlay of geologic periods, climatic conditions, water sources, geomorphic characteristics and river patterns, which were further classified into six groups via the $k$-Modes clustering algorithm (Huang, 1997, 1998). In view of the importance of both topographic properties and surface material compositions under the general category of loess landform in the Yellow River Basin, riverine habitats could be further identified in greater details based on morphological parameters including elevation, slope, lithological features, and soil texture.

Table 1. Integrated Geocode System for All Stream Orders

\begin{tabular}{|c|c|c|c|c|c|c|}
\hline \multirow{2}{*}{$\begin{array}{l}\text { Stream } \\
\text { order }\end{array}$} & \multirow{2}{*}{ Geocode } & \multicolumn{5}{|c|}{ Environmental factors } \\
\hline & & Geologic period & Climatic condition & Water source & Geomorphic feature & River pattern \\
\hline \multirow[t]{4}{*}{$1 \sim 10$} & 1 & early Pleistocene & tropics \& subtropics & precipitation & fluvial & straight \\
\hline & 2 & middle Pleistocene & $\begin{array}{l}\text { monsoon climate of } \\
\text { medium latitudes }\end{array}$ & groundwater & karst & meandering \\
\hline & 3 & late Pleistocene & temperate continental & lakes \& swamps & loess & braided \\
\hline & 4 & Holocene & plateau & glacier & glacial permafrost & anastomosed \\
\hline
\end{tabular}




\subsection{Quantification of Environmental Factors and Data Sources}

\subsubsection{Geological Period}

According to Dai (1983), Yellow River was generated in three stages of Quaternary period for different reaches, namely the Middle Pleistocene for riverhead-Yinchuan and Longmen-Taohuayu reaches, the Late Pleistocene for YichuanLongmen reach, and the Holocene for reach from Taohuayu to estuary.

\subsubsection{Climatic Condition}

The Yellow River Basin were divided into areas with tropical and sub-tropical climates, monsoon climate of medium latitudes, temperate continental climate, and plateau climate based on climatic regionalization map of China at 1:36 million resolutions (Liu, 2010).

\subsubsection{Water Sources}

Frozen Soil Map of Qinghai-Tibet Plateau at 1:3 million resolutions (Li and Cheng, 1996; National Earth System Science Data Sharing Infrastructure, National Science \& Technology Infrastructure of China available at http://www.geodata.cn) was used to quantify rivers supplied by snowmelt of glacier.

Regions where rivers are supplied with lakes and swamps were determined through the $1 \mathrm{~km}$ resolution Global Lakes and Wetlands Database (Lehner and Döll, 2004).

Regions where rivers were supplied by groundwater were quantified via the $1 \mathrm{~km}$ resolution aridity index $(A I)$ (Middleton et al., 1992). In regions where $A I<0.2$, runoff of rivers is supplied by groundwater since the ratio of actual evaporation to precipitation is equal to unity (Liu, 2014) when $A I=$ 0.2 , which implies all precipitation is consumed by evaporation instead of converting into runoff.

Rivers in the remaining regions were considered to be supplied by precipitation.

\subsubsection{Geomorphic Characteristics}

The loess geomorphic regions were firstly identified via the loess distribution map of China at 1:25 million (Liu, 1985) resolutions, and the glacial permafrost regions by Frozen Soil Map of Qinghai-Tibet Plateau at 1:3 million resolutions ( $\mathrm{Li}$ and Cheng, 1996). The remaining regions for rivers to flow through were identified as fluvial geomorphic regions.

Sub-habitats were further identification in terms of subfactors such as mean values of elevation and slope of rivers derived from the $30 \mathrm{~m}$ resolution Aster GDEM (Available at http://reverb.echo.nasa.gov/reverb/). The lithologic distribution of the Yellow River Basin was derived from $0.5^{\circ}$ resolution lithological map (Hartmann and Moosdorf, 2012) which is available at https://doi.pangaea.de/10.1594/PANGAEA.788537. The soil texture was quantified based on fractions of sand and clays (Davis and Bennett, 1927). Information of fractions of sand and clays were obtained from the $0.00833^{\circ}$ resolution soil particle-size distribution map (Wei et al., 2012) which was available at http://globalchange.bnu.edu.cn/research/ soil.

\subsubsection{River Pattern}

The sinuosity $(S)$, defined as ratio of the length along its winding path and the straight length from source to outlet, was used to distinguish straight rivers from meandering rivers. As $S>1.2$, rivers are regarded as meandering, and the remaining rivers are taken as straight rivers (Chen, 1992).

\section{Results and Discussions}

\subsection{Hierarchical Yellow River Networks}

Figure 2a illustrates the drainage networks of Yellow River Basin with stream order larger than 4. Ten spatially nested hierarchical orders are derived according to the Strahler streamordering rule. According to Strahler (1952), 899,415 rivers are identified, with catchment area ranging from 0.1 to $1,000,000$ $\mathrm{km}^{2}$. Large rivers with high stream-order form the backbone, and small rivers with low stream-order formulate the detailed network.

\subsection{Hierarchical Yellow River Networks}

By overlay of environmental factors including geological period (Figure 2b), climatic condition (Figure 2c), water source (Figure 2d), geomorphic characteristics (Figure 2e) and river pattern (Figure 2f) in the Yellow River Basin, 85 integrated geocodes were synthesized for 899,416 rivers with stream-order ranging from 1 to 10 .

Furthermore, six groups of representative riverine hab-

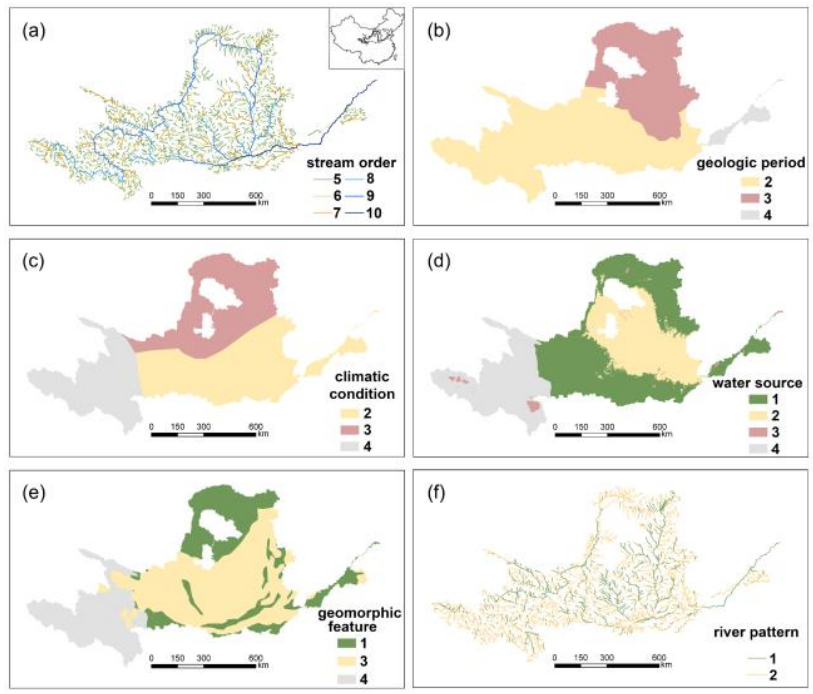

Figure 2. Distribution of: (a) Yellow River networks with different stream orders, (b) geologic period, (c) climatic condition, (d) water resource, (e) geomorphic characteristics, and (f) river pattern. 
itats were identified (Figure 3) after classification of geocodes (mainly according to climatic condition, water source, geomorphic characteristics) derived over the whole basin based on the $k$-Modes clustering algorithm. The corresponding geocodes for each of six groups were provided in Table 2.

The group I and group II include two types of riverine habitats with plateau climate and glacial permafrost landform. The plateau rivers in these regions are characterized by low water temperature due to vertical zonation, and thereby salinetolerant species, cold water species, and extreme climatic species. On the other hand, rivers with V-shaped valley are seldom found in these groups since land surface cannot be deeply incised due to the existence of permafrost, and bed materials are composed of debris with larger range of grain sizes. In addition, riverside has no large plants and the moss is widely developed. However, the major difference of rivers in groups I and II are the water sources. Rivers in group I is mainly supplied with glacier meltwater which is highly related to the temperature, demonstrating apparent seasonal fluctuation of flow. Those in group II are primarily supplied with lakes and swamps with less seasonal fluctuation of run-off.

The group III and group IV summarize typical riverine habitats with monsoon climate of medium latitudes and loess landform. The monsoon climate of medium latitudes shows obvious seasonal variation, hot and rainy in summer but cold and dry in winter, leading to seasonal biological life cycle. In loess geomorphic region, high sediment concertation is often observed in rivers due to severe soil erosion, leading to low transparency of flow water and weakening the photosynthetic

Table 2. Geocodes in Six Groups of Representative Aquatic Habitats

\begin{tabular}{ll}
\hline $\begin{array}{l}\text { Group } \\
\text { No. }\end{array}$ & Geocodes \\
\hline I & 24441,24442 \\
II & 24341,24342 \\
III & $22131,22132,23131,23132,32131,32132$, \\
& 42131,42132 \\
IV & $22231,22232,32231,32232,42231,42232$ \\
V & $22111,22112,23111,23112,32111,32112$, \\
& $3311,33112,42111,42112$ \\
VI & $23211,23212,33211,33212$ \\
\hline
\end{tabular}

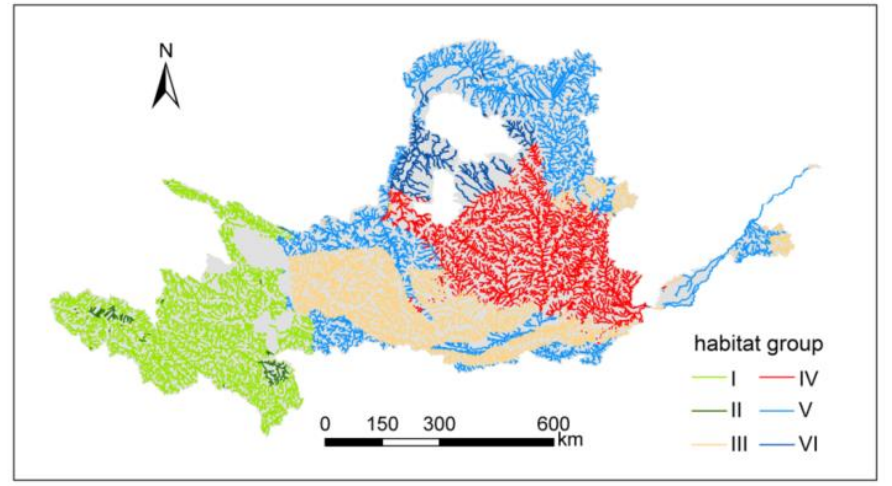

Figure 3. Six groups of representative riverine habitats in the Yellow River Basin. intensity of the producers. Meanwhile, the living space of benthos is limited due to the fine-grained loess sediment. Therefore, biodiversity would not be high in these river basins. Rivers in group III show apparent seasonal variations of runoff than those in group IV due to different water sources from precipitation and groundwater.

The group V and group VI cluster riverine habitats with fluvial landform. Rivers in Group V are mostly distributed in middle and lower areas of the Yellow River. In middle area of the basin, coarse-grained sediments provide sufficient living environments for benthos and fishes. The alternate appearance of pools and riffles lead to distribution of both lotic species and lentic species in this area. Meanwhile, the poorriffle systems are a high-quality spawning grounds of fishes (Li et al., 2012). In lower area of the basin, a great quantity of sediment deposited, leading to the raise of riverbed, which would greatly influence the diversity of benthos as well as fishes (Fu et al., 2010). Rivers in group VI are located in arid grasslands corresponding to temperate continental climate with scare precipitation, thus, rivers are mainly supplied by groundwater.

\subsection{Identification of Sub-habitats in the Loess Landform Region}

It can be found that geomorphic characteristics of river systems play a leading role in classification of the riverine habitats. However, under the same landform unit, there are still a variety of geomorphic features, which can be determined by two major factors, one is the topographic feature, and the other is the surface material composition. The topographic feature determines the river branching structure (Perron et al., 2012) and fluvial morphology (Wohl, 2014), while the surface material composition can affect sediment properties some associated hydrochemical characteristics in rivers (Boluwade and Madramootoo, 2015).

Taking the area of loess landform as an example, we can give reasonable descriptions on river habitats for fish communities based on more detailed geomorphic parameters such as elevation, slope, lithology, and soil texture (Figure $4 \mathrm{a} \sim$ 4d).

From a topographic perspective, elevation is an important factor for distinguishing plains $(<200 \mathrm{~m})$, hills $(200 \sim$ $500 \mathrm{~m}$ ) and mountains (> $500 \mathrm{~m}$ ) (Tian, 2009), which also influences other physical-chemical parameters including slope, water temperature, dissolved oxygen, and $\mathrm{pH}$ (Kisi et al., 2013). As illustrated in Figure 4a, the elevation in the loess landform region determines a longitudinal gradient along with the flow direction of the mainstream, causing corresponding change of fish assemblages. Elevation plays a key role in determining specie compositions of fish assemblages (Askeyev et al., 2017). In high altitude regions with extreme climatic conditions, there would be some endemic species such as cold-water species like trout, salmon, and char (Isaak et al., 2015). Species richness is found either increase (Askeyev et al., 2015, 2017) or decrease (Carvajal-Quintero et al., 2015) gradually with increasing elevation. It also has been reported 
that nearly $90 \%$ of the fish species were recorded in regions with elevation between 250 and 1,250 m (Jaramillovilla et al., 2010). Moreover, elevation also reflects the impact of human activities on the fish community. In general, abundance of fishes in the areas of high altitude would be promoted by better aquatic environments considering the less anthropogenic impacts in the upper rivers (Wu et al., 2014).

Slope is another important indicator of landform. As illustrated in Figure 4b, the steep lands (e.g., slope $>15^{\circ}$ ) are distributed in upstream regions of the primary or the secondary tributaries of the Yellow River. These areas mainly correspond to loess hilly-gully areas and rocky mountain areas with strong water erosion, thin soil layer, and exposed rock surface (Zhang et al., 2015) since soil is easily eroded during flood period. However, flat areas with small slope (e.g., slope $<15^{\circ}$ ) mainly correspond to loess depositional landforms e.g., loess tablelands and loess ridges, where water erosion process is weak and sediments are usually fine (Tian, 2009). Meanwhile, the slope can influence the distribution of fishes with different body sizes. Average body length and weight of fishes in the steep areas are larger than those in flat areas (Shepherd et al., 2009; Ru et al., 2010) since the steep areas more correspond to riffles, in which case, small fishes would be severely disturbed.

Figure $4 \mathrm{c}$ maps the lithological distribution of the loess landform region, $61 \%$ of which are covered with uncon- solidated loess sediment. The remaining areas are distributed with different rocks including volcanic rocks, plutonic rocks, carbonate sedimentary rocks and metamorphic rocks (Hartmann and Moosdorf, 2012), whose mineral compositions would determine major ion concentrations contained in water and total dissolved solid (TDS), and provide required elements for the growth of aquatic organisms. The basic rocks with low content of $\mathrm{SiO}_{2}$ and high content of $\mathrm{Ca}^{2+}, \mathrm{Al}^{3+}, \mathrm{Mg}^{2+}$, would lead to high alkalinity and alkalinity of water, while the acid rocks with high content of $\mathrm{SiO}_{2}$ would result in acid water body (Wang et al., 2008). The limestone regions also correspond to high value of $\mathrm{pH}$, and are mainly distributed with carbonate-preferred organisms. There is a clear separation in fish community structure between rocky-and soft-bottom habitats, that is, fish communities in rocky-bottom habitats are dominated by permanent non-commercial species, whereas the dominant species in soft-bottom habitats are juvenile fishes and commercial species (Pihl and Wennhage, 2002).

Distribution of soil texture properties in loess landform region which is quantified by fractions of sands and clays are mapped in Figure 4d. Coarse sediments (clay fraction $<25 \%$, sand fraction $>55 \%$ ) are distributed in the middle area of the Yellow River, and source areas of the major tributaries; whereas sandy clay, loamy clay, and silty clay whose clay fraction larger than $25 \%$ are mainly distributed in the confluent area of the major tributaries. Grain sizes of sediments on riverbed
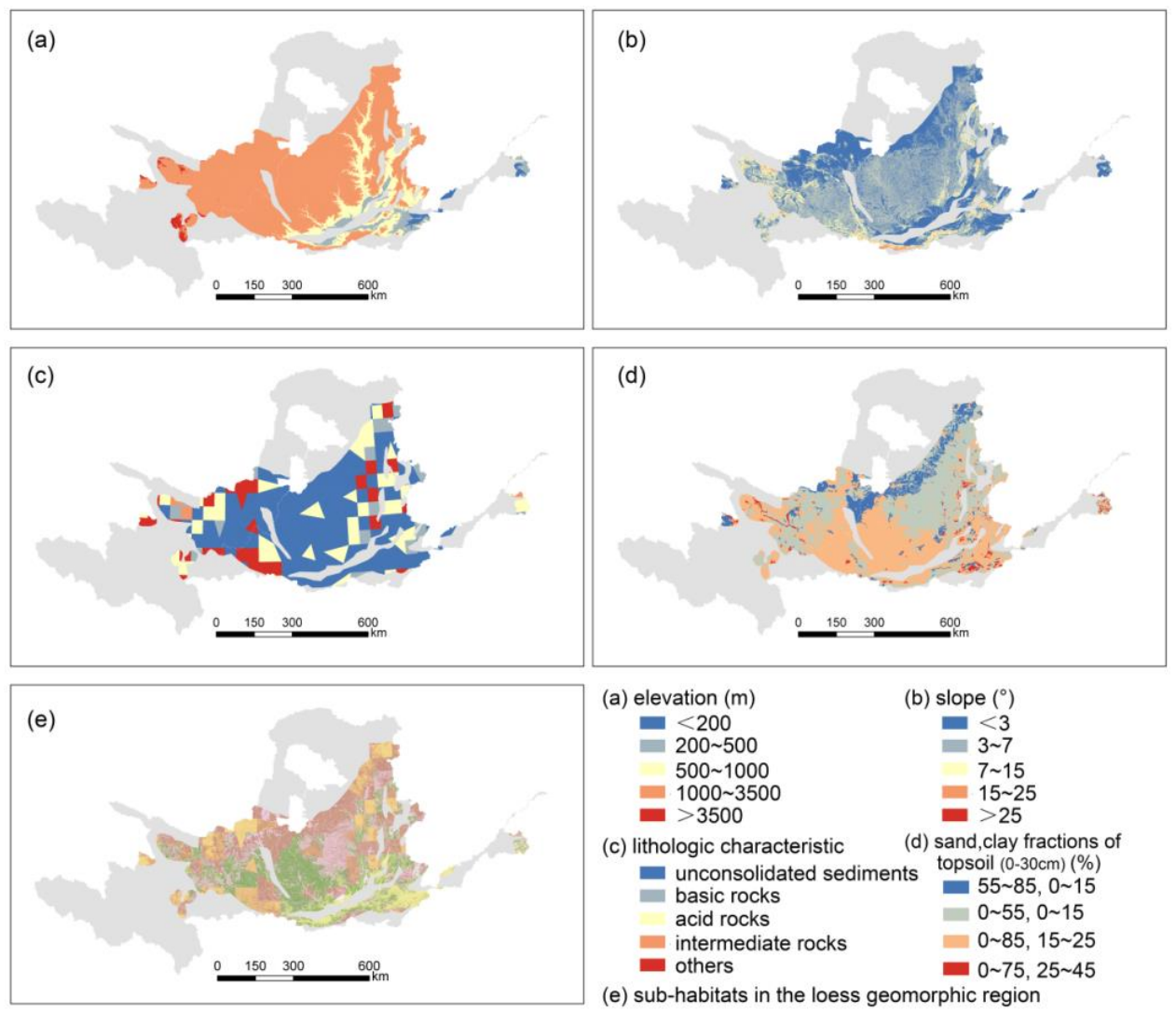

Figure 4. Distribution of: (a) elevation; (b) terrain slope; (c) lithologic characteristic; (d) sand and clay fractions of topsoil (0 $30 \mathrm{~m}$ ), and (e) sub-habitats in the loess geomorphic regionidentified based on overlay of (a) $\sim(\mathrm{d})$. 
surface are essential to spawning habitat quality of fishes (Riebe et al., 2014). Grain size of sediments is required coarse enough to resist water erosion (Tang, 2004) and to allow flowing through of the oxygen-rich water, but also required fine enough to enable female fishes to move sediments for structuring redds and deposit their eggs in the riverbed (Kondolf et al., 1993). Fishes with larger body size often make more riverbed area for spawning since they are more capable of moving larger sediment beneficial to higher fecundity (Riebe et al., 2014). Furthermore, grain size of sediment is the major influencing factor of juvenile fish distribution at small scale. Smaller fishes have a preference for fine-particle sediments, whereas larger fishes have less selectivity even if pebbles and granules are less common options for them (Stoner and Abookire, 2002).

Overlay of the aforementioned four geomorphic factors generates 313 sub-habitats (mean area of $1,212 \mathrm{~km}^{2}$ ) in the loess landform region, covering a total area of $380,163 \mathrm{~km}^{2}$ (Figure 4e). The Characteristics of fish community corre- sponding to different geomorphic factors were displayed in Table 3.

\subsection{Coupling of Aquatic Habitats and Topological Structure}

Spatial attributes could also be interpreted in terms of stream order. Using the Strahler stream-order scheme, ten orders of rivers are classified in the Yellow River Basin, which are expected to be correlated with aquatic habitats controlled by channel elevation, slope, fraction of sediments (clay and sand).

Figures $5 \mathrm{a}$ and $5 \mathrm{~b}$ show that both mean and median values of channel elevation and slope decrease with stream order (particularly from order 1 to order 7). The mean value of channel elevation decreases from 2,199 to $192 \mathrm{~m}$ when the stream order increases from 1 to 10 . The mean value of channel slope decreases from $12.28^{\circ}$ to $8.01^{\circ}$ from order 1 to order 10 , and reaches the minimum value $\left(5.82^{\circ}\right)$ at $7^{\text {th }}$ order. These results quantify the relationship between topographic

Table 3. Characteristics of Fish Community Corresponding to Different Geomorphic Factors

\begin{tabular}{lll}
\hline Geomorphic conditions & & Fish community \\
\hline Factor & Grade & eurythermal species \\
elevation & low & endemic species \\
slope & high & smaller-sized fishes \\
& high & larger-sized fishes \\
hardness of riverbed & low & juvenile fishes; commercial species \\
materials & high & non-commercial species \\
alkalinity of rock & low & silicate-preferred species \\
& high & carbonate-preferred species \\
grain size of sediment & low & smaller fishes; lentic species \\
& high & higher fecundity of fishes; lotic species \\
\hline
\end{tabular}
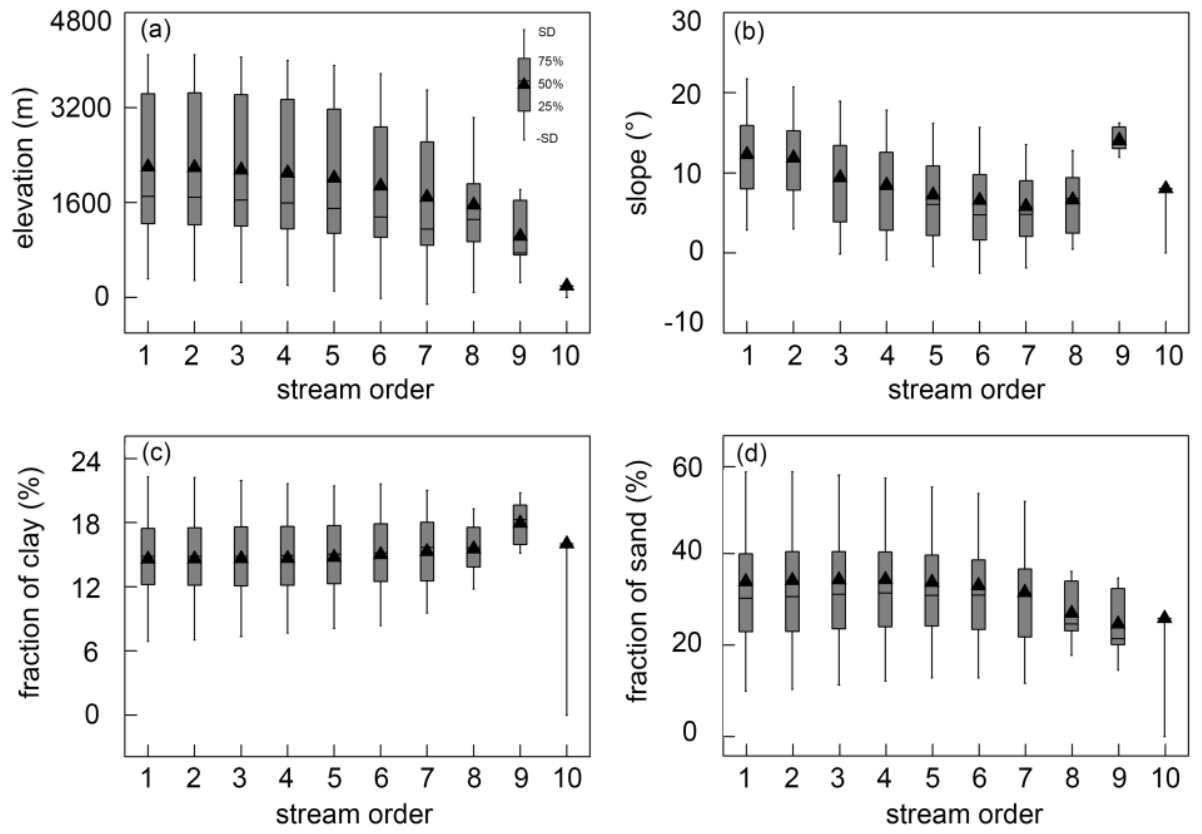

Figure 5. Relationship between (a) elevation and stream order; (b) slope and stream order; (c) fraction of clay and stream order; and (d) fraction of sand and stream order. 
conditions and hierarchical properties of rivers. Low-order rivers more correspond to habitats with higher elevation and steeper slope, and flat habitats with low altitude more frequently occur in high-order rivers.

Figures $5 \mathrm{c}$ and $5 \mathrm{~d}$ illustrate the fraction of clays and sands respectively in response to ten orders of rivers. For order $1 \sim 10$, the mean value of fraction of clay increases from 14.6 to $17.96 \%$, and reaches the maximum when stream order reaches 9 . Mean value of fraction of sand reduces from 33.86 to $24.62 \%$ and reaches the minimum when stream order gets to 9 . It seems that the greater stream-order is, the finer sediments would be encountered in the aquatic habitats in the Yellow River Basin.

Coupling of topographic features and surface material compositions is helpful to understand spatial distribution of riverine habitats in terms of stream orders, and hierarchical analysis based on primary geomorphic issues/factors would be of particular use to identify ecological responses in the context of river networks.

\subsection{Diversity of Riverine Habitats with Different Stream Orders}

\subsubsection{Diversity of Riverine Habitats among Rivers}

The diversities of riverine habitats described by the geocodes are highly relevant to stream orders. Figure 6a illustrates 85 independent geocodes $\left(N_{G}\right)$ screened from thousands of generated outputs over the whole Yellow River Basin. Coupling with rivers from order 1 to 10 , the $N_{G}$ simply decreases from 83 to 10 , in which the $N_{G}$ for headwater $\left(1^{\text {st }} \sim 3^{\text {rd }}\right.$ order herein) streams takes $96 \sim 98 \%$ of the total.
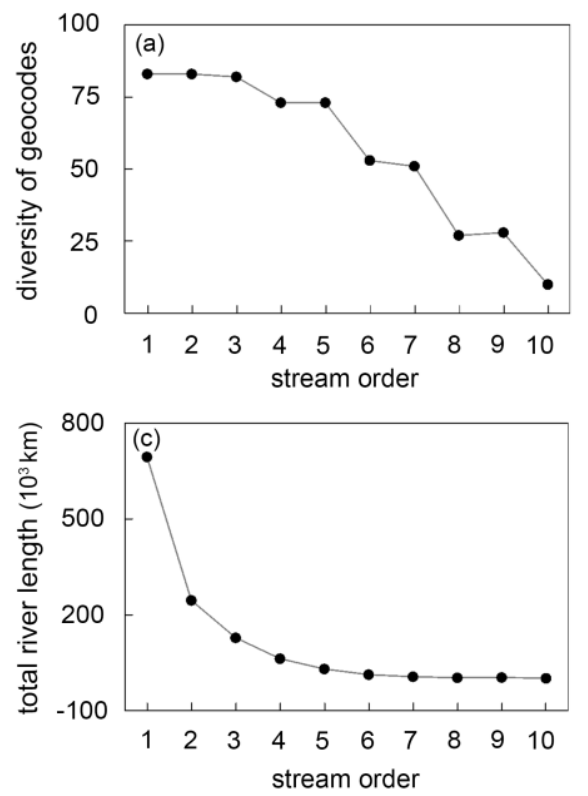

Headwater streams present greater $N_{G}$ due to two main reasons. Firstly, both number $(N)$ and length $(L)$ of lowerorder streams are much larger as shown in Figures $6 \mathrm{~b}$ and $6 \mathrm{c}$. The number of rivers reduces from 711,641 to 1 , and the total length of rivers decreases from 694,718 to $1,396 \mathrm{~km}$ with increase of stream orders from 1 to 10 . Headwater streams contribute about $95 \%$ of the total number and $79 \%$ of the total length of rivers, suggesting their irreplaceable role in promoting diversity of riverine habitats. Secondly, headwater streams are more spatially isolated due to the branching structure of river networks. The spatial isolation of low streamorder rivers could be quantified by an index called fractal dimension (D) (Mandelbrot, 1967) with the box counting algorithm (Beauvais and Montgomery, 1997):

$D=\lim _{\varepsilon \rightarrow 0}[\log N(\varepsilon) / \log (1 / \varepsilon)]$

where $N(\varepsilon)$ is the number of boxes of side length $\varepsilon$ required to cover the set.

Fractal dimensions for each of the ten orders of rivers are illustrated in Figure 6d, from which we can see that the value of $D$ also decreases with increasing stream order. Furthermore, $D$ and $N_{G}$ are found positively correlated $\left(R^{2}=0.49\right)$. On the average, $N_{G}$ decreases by $22 \%$ with per-unit decrease of $D$. The low-order streams with higher fractal dimension are capable of spreading to extensive areas from the tips of a dendritic fluvial network, which leads to pronounced habitat variations among headwater streams.

Since headwater streams present greater among-stream discrepancies in local habitat characteristics than larger rivers,
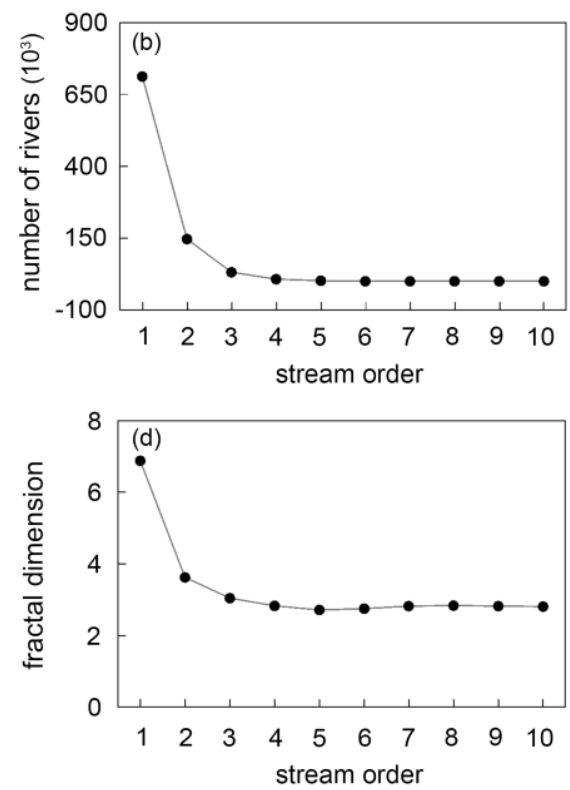

Figure 6. Hierarchical properties of (a) diversity of geocodes among rivers, (b) number of rivers, (c) total length of rivers, and (d) fractal dimension. 
there is a high degree of variability in species composition among headwater streams which is known as $\beta$ diversity (Whittaker, 1960). The significant contribution of headwater streams to biodiversity (especially $\beta$ diversity) has been reported recently (Besemer et al., 2013; Biggs et al., 2017; Baattrup-Pedersen et al., 2017), which is further confirmed in the present work though traditionally headwater streams have been considered depauperate (RCC, Vannote et al., 1980) on stream network biodiversity.

\subsubsection{Diversity of Riverine Habitats within a River}

Rivers could be segmented into reaches in terms of geocodes which reflect spatial heterogeneity of principal environmental factors within a single river, leading to habitat fragmentation which is characterized by two indexes $F I_{1}$ and $F I_{2}$ respectively defined as follows:

$F I_{l}=N_{l} / N$

and
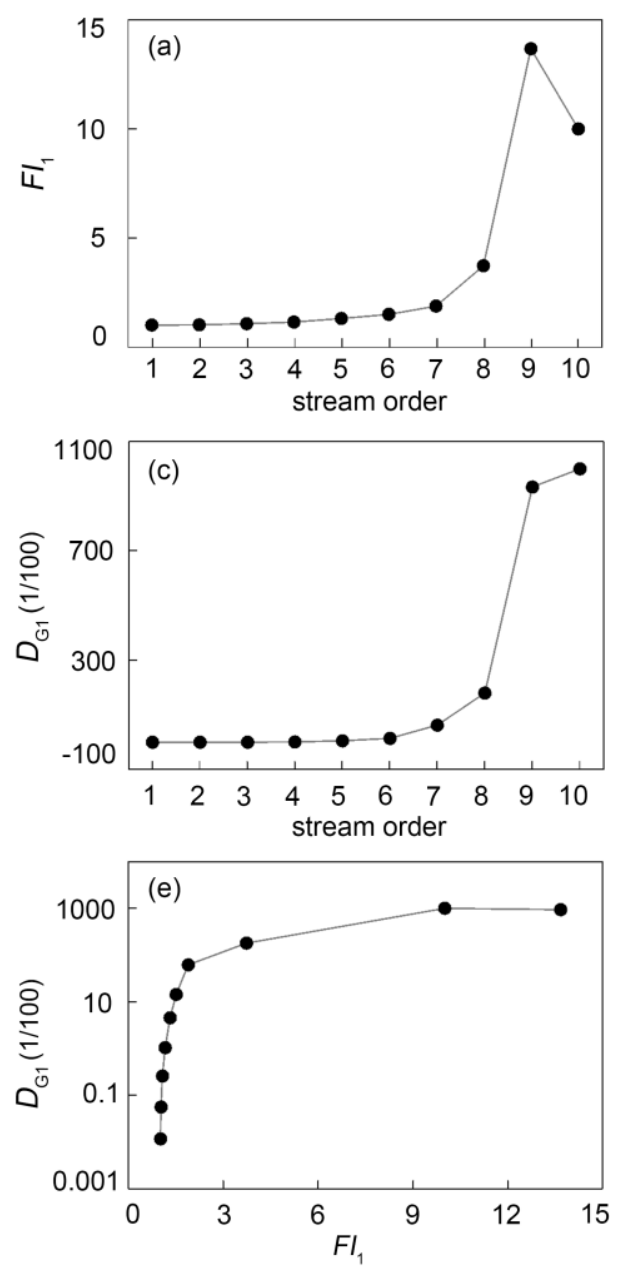

$$
F I_{2}=L_{1} / L_{2}
$$

where $N_{l}$ is number of reaches, and $N$ is number of rivers of specific order; $L_{1}$ and $L_{2}$ are average length of rivers and reaches of specific order, respectively.

Figures $7 \mathrm{a}$ and $7 \mathrm{~b}$ illustrate both $F I_{1}$ and $F I_{2}$ for ten orders of rivers. Increase of $F I_{1}$ (from 1.02 to 13.67) and $F I_{2}$ (from 1.07 to 14.33 ) reveal that degree of habitat fragmentation of rivers grows with increasing stream order $\left(1^{\text {st }} \sim 9^{\text {th }}\right.$ but except the $\left.10^{\text {th }}\right)$. For clarity, another two parameters $\left(D_{G I}\right.$ and $D_{G 2}$ ) are further introduced to present the average habitat diversity within a river:

$D_{G l}=N_{G} / N$

$D_{G 2}=N_{G} / L$

As illustrated in Figures $7 \mathrm{c}$ and $7 \mathrm{~d}, D_{G 1}$ increases from 0.01 to 1,000 when stream order increase from 1 to 10 , while $D_{G 2}$ increases with stream order for order $1 \sim 8$, and decreases
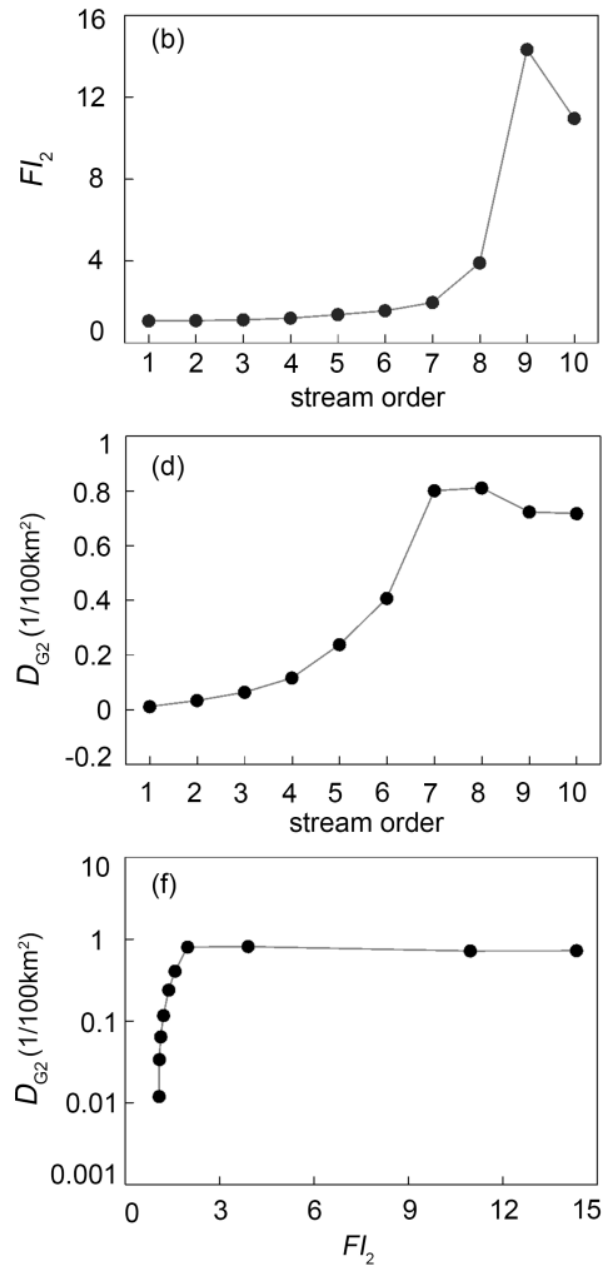

Figure 7. Characterization of fragmental degree of rivers (a) $F I_{l}$, and (b) $F I_{2}$, geocodes (c) $D G_{l}$, and (d) $D G_{2}$ within a river, and their relationship (e) $D G_{1}$ and $F I_{1}$, (f) $D G_{2}$ and $F I_{2}$. 
from order 8 to order 10. This implies that a low-order stream exhibits more homogeneity of habitats, but a high-order river tends to present heterogeneity of habitats. And higher heterogeneity of habitats within a river indicates a higher complexity of riverine habitats.

The relationship between river fragmentation and average habitat diversity within a river are also investigated (see Figures $7 \mathrm{e}$ and $7 \mathrm{f}$ ). In the perspective of number of rivers with given stream orders (Figure $7 \mathrm{e}$ ), $D_{G 1}$ slowly increases (from 0.03 to 0.09 ) for rivers from order 1 to 4 , then rapidly increases $(0.22$ to 1.24$)$ from order 4 to 7 , and followed by a decrease (from 0.63 to -0.18 ) for rivers from order 7 to 10 . With increase of the stream order, the positive feedback of habitat diversity within a river is declined to degree of habitat fragmentation of rivers. In the perspective of length of rivers with given stream orders, similar relations are found between $D_{G 2}$ and $F_{2}$ (Figure $7 \mathrm{f}$ ). Overall, the habitat diversity within a river of lower stream-order $(1 \sim 3)$ is generally small and getting higher for moderate stream-order $(4 \sim 7)$.

The highest environmental heterogeneity of rivers with moderate orders demonstrates an increase of ecological diversity from headwaters to mid-sized streams. Existing literatures on fishes (Muneepeerakul et al., 2008) and diatom (Stenger-Kovács et al., 2014) confirm the view of enhancive local diversity (characterized by alpha diversity, Whittaker, 1960) corresponding to stream order.

\subsection{Implications for River Ecology}

Interaction between dendritic river networks and habitat diversity is one of the major concerns on biodiversity. For example, previous studies have indicated the consequences of underestimation for biodiversity in river networks when small streams are ignored (Benstead and Leigh, 2012). Our systematic study on the role of headwater streams as well as mid-sized rivers on differentiation of aquatic habitats is helpful to get insights into biological responses in river networks. The coupling of habitats and river networks could be implemented through geomorphic properties, in particular factors describeing surface materials and topographic conditions, and thereby allows to investigate the community assembly mechanism in the hierarchical aquatic systems.

The present work is potentially useful for explaining the controversy about dominant driving force of community construction and biodiversity in terms of Niche and Neutral theories in riverine habitats. Niche-based theory of community assembly believes that community construction is a screening process, in which local species are selected from largescale species reservoirs through multiple environmental filtering and biological interacting (Shea and Chesson, 2002), whereas the neutral theory of biodiversity assumes that community diversity is only the result of diffusion and random action, which is independent with species attributes and environmental factors (Hubbell, 2005; Liu et al., 2017; Sun et al., 2017; Yu et al., 2017). More recently, some attempts have been made for reconciliation of these two theories (Niu et al., 2009; Fan et al., 2017b). Our study reveals that Neutral theory is more suitable for describing aquatic habitats with homogeneous geographical features, and headwater streams (with lower stream orders) become dominant to the topologic structure of river networks. However, Niche theory is more appropriate for describing aquatic habitats with varied climatic and geographyic conditions, and larger rivers (with higher stream orders) should be the major concern because of increasing habitat heterogeneity and diverse response of biological community.

\section{Conclusions}

An integrated approach is proposed for identification of aquatic habitats in river networks in terms of geocodes derived from geologic periods, climatic conditions, water sources, geomorphic characteristics and river patterns. In particular, 6 groups of aquatic habitats in the Yellow River Basin have been classified, and 313 sub-habitats were further derived with consideration of both topographic condition and surface material composition in the loess geomorphic regions. By coupling the generated habitats with river networks in the Yellow River Basin, the role of rivers with different stream orders has been systematically examined, in particular the contribution of headwater streams to diversity of aquatic habitats among rivers and mid-sized rivers to the diversity within a river, which also allows a better understanding of assembly mechanisms of biological communities in hierarchical river systems.

Acknowledgements. Financial support from the National Natural Science Foundation of China (Grant No. 91647211 and 51721006) is very much appreciated.

\section{Notation List}

AI: aridity index, a function of precipitation and potential evapo-transpiration.

$S$ : sinuosity, ratio of the length along its winding path and the straight length from source to outlet.

$N_{G}$ : number of independent geocodes.

$N$ : number of rivers of specific order.

$L$ : total length of rivers of specific order.

$D$ : fractal dimension.

$\varepsilon$ : side length of box.

$N(\varepsilon)$ : the number of boxes of required to cover the set.

$N_{l}$ : number of reaches.

$L_{1}$ : average length of rivers of specific order.

$L_{2}$ : average length of reaches of specific order.

$F I_{1}$ : parameter of habitat fragmentation, $F I_{l}=N_{l} / N$.

$F I_{2}$ : parameter of habitat fragmentation, $F I_{2}=L_{1} / L_{2}$.

$D_{G I}$ : average habitat diversity within a river in terms of number of rivers, $D_{G I}=N_{G} / N$.

$D_{G 2}$ : average habitat diversity within a river in terms of river length, $D_{G 2}=N_{G} / L$. 


\section{References}

An, C.J., Huang G., Yao, Y., and Zhao, S. (2016). Emerging usage of electrocoagulation technology for oil removal from wastewater: A review. Sci. Total Environ., 579, 537-556. http://doi.org/10.1016/j. scitotenv.2016.11.062

Ardli, E.R. and Wolff, M. (2009). Land use and land cover change affecting habitat distribution in the Segara Anakan lagoon, Java, Indonesia. Reg. Environ. Chang. 9(4), 235-243. https://doi.org/10. 1007/s10113-008-0072-6

Askeyev, A., Askeyev, O., Yanybaev, N., Askeyev, I., Monakhov, S., Marić, S., and Hulsman, K. (2017). River fish assemblages along an elevation gradient in the eastern extremity of Europe. Environ. Biol. Fishes. 100(5), 585-596. https://doi.org/10.1007/s10641-0170588-z

Askeyev, O., Askeyev, I., Askeyev, A., Monakhov, S., and Yany-baev, N. (2015). River fish assemblages in relation to environmental factors in the eastern extremity of Europe (Tatarstan Republic, Russia). Environ. Biol. Fishes. 98(5), 1277-1293. https://doi.org/10. 1007/s10641-014-0358-0

Baattrup-Pedersen, A., Larsen, S.E., Andersen, D.K., Jepsen, N., Nielsen, J., and Rasmussen, J.J. (2017). Headwater streams in the EU water framework directive: evidence-based decision support to select streams for river basin management plans. Sci. Total Environ., 613(1), 1048-1054. https://doi.org/10.1016/j.scitotenv.20 17.09.199

Bai, R., Li, T.J., Huang, Y.F., Li, J.Y., and Wang, G.Q. (2015). An efficient and comprehensive method for drainage network extraction from DEM with billions of pixels using a size-balanced binary search tree. Geomorphology, 238, 56-67. https://doi.org/10.1016/j. geomorph.2015.02.028

Beauvais, A.A. and Montgomery, D.R. (1997). Are channel networks statistically self-similar? Geology, 25(12), 1063- 1066. https://doi org/10.1130/0091-7613(1997)025\%3C1063: ACNSSS\%3E2.3.CO;2

Benda, L., Poff, N.L., Miller, D., Dunne, T., Reeves, G., Pess, G., and Pollock, M. (2004). The network dynamics hypothesis: how channel networks structure riverine habitats. BioScience, 54(5), 413-427. https://doi.org/10.1641/0006-3568(2004)054[0413:TNDH$\mathrm{HC}$ 2.0.CO;2

Benstead, J.P. and Leigh, D.S. (2012). An expanded role for river networks. Nat. Geosci., 5(10), 678-679. https://doi.org/10.1038/ngeo1593

Besemer, K., Singer, G., Quince, C., Bertuzzo, E., Sloan, W., and Battin, T.J. (2013). Headwaters are critical reservoirs of microbial diversity for fluvial networks. Proc. R. Soc. B-Biol. Sci., 80(1771). https://doi.org/10.1098/rspb.2013.1760

Biggs, J., Von Fumetti, S., and Kelly-Quinn, M. (2017). The importance of small waterbodies for biodiversity and ecosystem services: implications for policy makers. Hydrobiologia, 793(1), 3-39. https://doi. org/10.1007/s10750-016-3007-0

Boitsidis, A.J., Gurnell, A.M., Scott, M., Petts, G.E., and Armitage, P.D. (2006). A decision support system for identifying the habitat quality and rehabilitation potential of urban rivers. Water Environ. J., 20(3), 130-140. https://doi.org/10.1111/j.1747-6593.2005.00005.x

Boluwade, A. and Madramootoo, C. (2015). Determining the influence of land use change and soil heterogeneities on discharge, sediment and phosphorus. J. Environ. Inf., 25(2), 126-135. https:// doi.org/10.3808/jei.201500290

Buffagni, A., Crosa, G.A., Harper, D.M., and Kemp, J.L. (2000). Using macroinvertebrate species assemblages to identify river channel habitat units: an application of the functional habitats concept to a large, unpolluted Italian river (River Ticino, northern Italy). Hydrobiologia, 435(1-3), 213-225. https://doi.org/10.1023/ A:1004124717508
Campbell, R.E. and Mcintosh, A.R. (2017). Space-time interactions and invertebrate assemblage change in stream networks. Austral Ecol. 42(2), 227-237. https://doi.org/10.1111/aec.124 25

Carvajal-Quintero, J.D., Escobar, F., Alvarado, F., Villa-Navarro, F.A., Jaramillo-Villa, Ú., and Maldonado-Ocampo, J.A. (2015). Variation in freshwater fish assemblages along a regional elevation gradient in the northern Andes, Colombia. Ecol. Evol., 5(13), 26082620. https://doi.org/10.1002/ece3.1539

Ceola, S., Bertuzzo, E., Singer, G., Battin, T.J., Montanari, A., and Rinaldo, A. (2014). Hydrologic controls on basin-scale distribution of benthic invertebrates. Water Resour. Res., 50(4), 2903-2920. https://doi.org/10.1002/2013WR015112

Chen, B.C. (1992). Classification of river pattern. J. Sediment Res., (1), 100-104. (in Chinese)

Czuba, J.A. and Foufoula-Georgiou, E. (2015). Dynamic connectivity in a fluvial network for identifying hotspots of geomorphic change. Water Resour. Res., 51(3), 1401-1421. https://doi.org/10.1002/20 14WR016139

Dai, Y.S. (1983). A brief history of formation and development of the Yellow River. Yellow River, 6, 4-9. (in Chinese)

Davis, R.O.E. and Bennett, H.H. (1927). Grouping of soils on the basis of mechanical analysis, U.S. Dep. Agric., Departmental Circulation No. 419.

Editorial Committee of Encyclopedia of Rivers and Lakes in China. (2014). Encyclopedia of Rivers and Lakes in China. Yellow River Volume, China Water Power Press. (in Chinese)

Fan, Y. R., Huang, G. H., Baetz, B. W., Li, Y. P., and Huang, K. (2017a). Development of a copula - based particle filter (coppf) approach for hydrologic data assimilation under consideration of parameter interdependence. Water Resour. Res., 53(6), 4850-4875. http://doi.org/10.1002/2016WR020144

Fan, Y. R., Huang, G. H., Baetz, B. W., Li, Y. P., Huang, K., Chen, X., and Gao M. (2017b). Development of integrated approaches for hydrological data assimila-tion through combination of ensemble kalman filter and particle filter methods. J. Hydrol., 550, 412-426. https:// doi.org/10.1016/j.jhydrol.2017.05.010

Fu, X.C., Ye, L., Xu, Y.Y., and Cai, Q.H. (2010). Survey of water quality and benthos in the Yellow River basin. Ecol. Sci., 29(1), 1-7. https://doi.org/10.3969/j.issn.1008-8873.2010.01.001. (in Chinese)

Hartmann, J. and Moosdorf, N. (2012). The new global lithological map database GLiM: A representation of rock properties at the Earth surface. Geochem. Geophys. Geosyst., 13(12). https://doi. org/10.1029/2012GC004370

He, L., Wang, G.Q., and Li, T.J. (2009). Catchment division of the water and sediment yield system and drainage network codification of the key region in the middle Yellow River basin. $J$. Sediment Res., (2), 39-45. (in Chinese)

He, L., Wang, G.Q., and Zhang, C. (2012). Application of loosely coupled watershed model and channel model in Yellow River, China. J. Environ. Inf., 19(1), 30-37. https://doi.org/10.3808/jei. 201200206

He, X.J. (2017). Information on impacts of climate change and adaptation in China. J. Environ. Inf., 29(2), 110-121. https://doi. org/10.3808/jei.201700367

Horton, R.E. (1945). Erosional development of streams and their drainage basins: hydro-physical approach to quantitative morphology. Geol. Soc. Am. Bull., 56(3), 275-370.

Hotchkiss, E.R., Hall, R.O., Sponseller, R.A., Butman, D., Klaminder, J., Laudon, H., Rosvall, M., and Karlsson, J. (2015). Sources of and processes controlling $\mathrm{CO}_{2}$ emissions change with the size of streams and rivers. Nat. Geosci., 8(9), 696-699. https://doi.org/10. 1038/ngeo2507

Huang, G.H. and Loucks, D.P. (2000). An inexact two-stage stochastic programming model for water resources management un- 
der uncertainty. Civ. Eng. Environ. Syst., 17(2), 95-118. http://doi. org/10.1080/02 630250008970277

Huang G.H. (1998). A hybrid inexact-stochastic water management model. Eur. J. Oper. Res., 107(1), 137-158. http://doi.org/10.1016/ S0377-2217(97)00144-6

Huang, G. H., Huang, Y. F., Wang, G. Q., and Xiao, H. N. (2006). Development of a forecasting system for supporting remediation design and process control based on napl-biodegradation simulation and stepwise-cluster analysis. Water Resour. Res., 42(6), 650-664. http://doi.org/10.1029/2005WR004006

Huang, Z.X. (1997). Clustering large datasets with mixed numeric and categorical values. Proc of PAKDD'97, Singapore, World Scientific, pp. 21-35.

Huang, Z.X. (1998). Extensions to the k-means algorithm for clustering large data sets with categorical values. Data Min. Knowl. Discov., 2(3), 283-304. https://doi.org/10.1023/A:1009769707641

Hubbell, S.P. (2005). Neutral theory in community ecology and the hypothesis of functional equivalence. Funct. Ecol., 19(1), 166-172. https://doi.org/10.1111/j.0269-8463.2005.00965.x

Inglis, L., Boothroyd, I.K.G., and Brierley, G. (2008). Effectiveness of the river environment classification in the Auckland Region. $N$. Z. Geogr., 64(3), 181-193. https://doi.org/10.1111/j.1745-7939.2008. 00144.x

Isaak, D.J., Young, M.K., Nagel, D.E., Horan, D.L., and Groce, M.C. (2015). The cold-water climate shield: delineating refugia for preserving salmonid fishes through the 21 st century. Glob. Change Biol., 21(7), 2540-2553. https://doi.org/10.1111/gcb.12879

Jaramillovilla, U., Maldonadoocampo, J.A., and Escobar, F. (2010). Altitudinal variation in fish assemblage diversity in streams of the central Andes of Colombia. J. Fish Biol., 76(10), 2401-2417. https://doi.org/10.1111/j.1095-8649.2010.02629.x

Kisi, O., Akbari, N., Sanatipour, M., Hashemi, A., Teimourzadeh, K., and Shiri, J. (2013). Modeling of dissolved oxygen in river water using artificial intelligence techniques. J. Environ. Inf., 22(2), 92-101. https://doi.org/10.3808/jei.201300248

Kondolf, G.M., Sale, M.J., and Wolman, M.G. (1993). Modification of fluvial gravel size by spawning salmonids. Water Resour. Res. 29(7), 2265-2274, https://doi.org/10.1029/93WR00401

Lave, J. (2015). Earth science: Landscape inversion by stream piracy. Nature, 520(7548), 442-444. https://doi.org/10.1038/520442a

Lehner, B. and Döll, P. (2004). Development and validation of a global database of lakes, reservoirs and wetlands. J. Hydrol., 296(1-4), 1-22. https://doi.org/10.1016/j.jhydrol.2004.03.028

Li, Q., Lv, P.Y., Peng, Q.D., and Li, C. (2012). Analysis of the topography of the coreius hererodon spawning ground in national nature reserve of rare and endemic fish in Yangtze River upstream area based on the distribution of pool-riffles. J. Sichuan Univ., Engineering Science Edition, 273-278.

Li, S.D. and Cheng, G.D. (1996). Map of Frozen Ground on Qinghai -Xizang Plateau. Gansu Culture Press.

Liu, C.M. (2014). Hydrogeography of China, Science Press. (in Chinese)

Liu, D.S. (1985). Loess and Environment, Science Press. (in Chinese)

Liu, J., Li, Y. P., Huang, G. H., Zhuang, X. W., and Fu, H. Y. (2017). Assessment of uncertainty effects on crop planning and irrigation water supply using a monte carlo simulation based dual-interval stochastic programming method. J. Cleaner Prod., 149, 945-967. http://doi.org/10.1016/j.jclepro.2017.02.100

Liu, M.G. (2010). Atlas of Physical geography of China, SinoMaps Press. (in Chinese)

Li, Y. P., Huang, G. H., and Nie, S. L. (2010). Planning water reources management systems using a fuzzy-boundary intervalstochastic programming method. Adv. Water Resour, 33(9), 11051117. http://doi.org/10.101 6/j.advwatres.2010.06.015
Li, Y. P., Huang, G. H., Huang, Y. F., and Zhou, H. D. (2009). A multistage fuzzy-stochastic programming model for supporting sustainable water-resources allocation and management. Environ. Model. Software, 24(7), 786-797. http://doi.org/10.1016/j.envsoft. 2008. 11.008

Li, Y. P., Huang, G. H., Nie, S. L., and Liu, L. (2008). Inexact multistage stochastic integer programming for water resources management under uncertainty. J. Environ. Manage., 88(1), 93107. http://doi.org/10.10 16/j.jenvman.2007.01.056

Lv, Y., Huang, G. H., Li, Y. P., Yang, Z. F., Liu, Y., Cheng, G. H.(2010).Planning regional water resources system using an interval fuzzy bi-level programming method. J. Environ. Inf., 16(2), 43-56. http://doi.org/10.3808/jei. 201000177

Ma, Z.Z., Wang, Z.J., Xia, T., Gippel, C.J., and Speed, R. (2014). Hydrograph-based hydrologic alteration assessment and its application to the Yellow River. J. Environ. Inf., 23(1), 1-13. https://doi. org/10.3808/jei.201400252

Mandelbrot, B. (1967). How long is the coast of britain? Statistical self-similarity and fractional dimension. Science, 156(3775), 636638. https://doi.org/10.1126/science.156.3775.636

Mckenna, J.E., Schaeffer, J.S., Stewart, J.S., and Slattery, M.T. (2015). Development of a spatially universal framework for classifying stream assemblages with application to conservation planning for Great Lakes lotic fish communities. Restor. Ecol., 23(2), 167-178. https://doi.org/10.1111/rec.12146

Middleton, N., Thomas, D.S., and UNEP. (1992). World Atlas of Desertification, Edward Arnold.

Milly, P.C.D., Dunne, K.A., and Vecchia, A.V. (2005). Global pattern of trends in streamflow and water availability in a changing climate. Nature, 438(7066), 347-350. https://doi.org/10.1038/nature 04312

Muneepeerakul, R., Bertuzzo, E., Lynch, H.J., Fagan, W.F., Rinaldo, A., and Rodriguez-Iturbe, I. (2008). Neutral Metacommunity models predict fish diversity patterns in Mississippi-Missouri basin. Nature, 453(7192), 220-222. https://doi.org/10.1038/nature 06813

National Earth System Science Data Sharing Infrastructure, National Science \& Technology Infrastructure of China. http://www.geodata. cn

Ni, J.R. and Gao, X.W. (2011a). Comprehensive approach for classification of river systems and identification of ecological characteristics I : Methodology. J. Hydraul. Eng., 42(9), 1009-1016. (in Chinese)

Ni, J.R. and Gao, X.W. (2011b). Comprehensive approach for classification of river systems and identification of ecological characteristics II: Applications. J. Hydraul. Eng., 42(10), 1177-1184. (in Chinese)

Ni, J.R., Wu,A., Li, T.H., Yue, Y., and Borthwick, A.G.L. (2014). Efficient soil loss assessment for large basins using smart coded polygons. J. Environ. Inf., 23(2), 47-57. https://doi.org/10.3808/jei. 201400264

Niu, K.C., Liu, Y.N., Shen, Z.H., He, F.L., and Fang, J.Y. (2009). Community assembly: the relative importance of neutral theory and niche theory. Biodivers. Sci., 17(6), 579-593. https://doi.org/10. 3724/SP.J.1003.2009.09142. (in Chinese)

Perron, J.T., Richardson, P.W., Ferrier, K.L., and Lapotre, M. (2012). The root of branching river networks. Nature, 492(7427), 100-103. https://doi.org/10.1038/nature11672

Pihl, L. and Wennhage, H. (2002). Structure and diversity of fish assemblages on rocky and soft bottom shores on the Swedish west coast. J. Fish Biol., 61, 148-166. https://doi.org/10.1006/jfbi.20 02.2074

Regnier, P., Friedlingstein, P., Ciais, P., Mackenzie, F.T., Gruber, N., Janssens, I.A. et al., and Thullner, M. (2013). Anthropogenic 
perturbation of the carbon fluxes from land to ocean. Nat. Geosci., 6(8), 597-607. https://doi.org/10.1038/ngeo1830

Rice, S.P. (2017). Tributary connectivity, confluence aggradation and network biodiversity. Geomorphology, 277(15), 6-16. https://doi. org/10.1016/j.geomorph.2016.03.027

Riebe, C.S., Sklar, L.S., Overstreet, B.T., and Wooster, J.K. (2014). Optimal reproduction in salmon spawning substrates linked to grain size and fish length. Water Resour. Res., 50(2), 898-918. https://doi.org/10.1002/2013WR014231

Ru, H.J., Wang, H.J., Zhao, W.H., Shen, Y.Q., Wang, Y., and Zhang, X.K. (2010). Fishes in the mainstream of the Yellow River: assemblage characteristics and historical changes. Biodiv. Sci., 18(2), 169-174. (in Chinese)

Shea, K. and Chesson, P. (2002). Community ecology theory as a framework for biological invasions. Trends Ecol. Evol., 17(4), 170-176. https://doi.org/10.1016/S0169-5347(02)02495-3

Shepherd, S.A., Brook, J.B., and Xiao, Y. (2009). Environmental and fishing effects on the abundance, size and sex ratio of the bluethroated wrasse, Notolabrus tetricus, on South Australian coastal reefs. Fisheries Manag. Ecol., 17(3), 209-220. https://doi.org/10. 1111/j.1365-2400.2009.00697.x

Shreve, R.L. (1966). Statistical law of stream numbers. J. Geol. 74(1), 17-37. https://doi.org/10.1086/627137

Stenger-Kovács, C., Tóth, L., Tóth, F., Hajnal, E., and Padisák, J. (2014). Stream order-dependent diversity metrics of epilithic diatom assemblages. Hydrobiologia, 721(1), 67-75. https://doi.org/10. 1007/s10750-013-1649-8

Stoner, A.W. and Abookire, A.A. (2002). Sediment preferences and size-specific distribution of young-of-the-year Pacific halibut in an Alaska nursery. J. Fish Biol., 61(3), 540-559. https://doi.org/10. 1006/jfbi.2002.2056

Strahler, A.N. (1952). Hypsometric (area altitude) analysis of erosional topography. Geol. Soc. Am. Bull, 63(11), 1117-1142. https://doi.org/10.1130/0016-7606(1952)63[1117:HAAOET]2.0.C $\mathrm{O} ; 2$

Strahler, A.N. (1957). Quantitative analysis of watershed geomorphology. Eos, Trans. Am. Geophys. Uni., 38(6), 913-920. https:// doi.org/10.1029/TR038i006p00913

Sun, J., Li, Y. P., Huang, G. H., and Wang, C. X. (2017). Analysis of interactive effects of dem resolution and basin subdivision level on runoff simulation in kaidu river basin, china. Hydrol. Res., 48(4), 1100-1117. http://doi.org/10.2166/nh.2016.332

Swan, C.M. and Brown, B.L. (2017). Metacommunity theory meets restoration: isolation may mediate how ecological communities respond to stream restoration. Ecol. Appl., 27(7), 2209-2219. https://doi.org/10.1002/eap.1602

Syvitski, J.P.M, Vörösmarty, C.J., Kettner, A.J., and Green, P. (2005). Impact of humans on the flux of terrestrial sediment to the global coastal ocean. Science, 308(5720), 376-380. https://doi.org/10.11 26/science. 1109454

Tang, K.L. (2004). Soil and Water Conservation in China, Science Press. (in Chinese)

Tian, M.Z. (2009). Quaternary Geology and Geomorphology, Geological Publishing House. (in Chinese)

Vannote, R.L., Minshall, G.W., Cummins, K.W., Sedell, J.R., and Gushing, C.E. (1980). The river continuum concept. Can. J. Fish. Aquat. Sci., 37(1), 130-137. https://doi.org/10.1139/f80-017

Veltri, M., Veltri, P., and Maiolo, M. (1996). On the fractal description of natural channel networks. J. Hydrol., 187(1-2), 137-144. https://doi.org/10.1016/S0022-1694(96)03091-0

Wang, G.H., Wang, X.L., and Yu, X.Q. (2008). Synthetic Geology, Geological Publishing House. (in Chinese)
Wang, L., Huang, G., Wang, X., and Zhu, H. (2018). Risk-based electric power system planning for climate change mitigation through multi-stage joint-probabilistic left-hand-side chance-constrained fractional programming: a canadian case study. Renew. Sustainable Energy Rev., 82, 1056-1067. https://doi.org/10.1016/ j.rser.2017.09.098

Wei, S.G., Dai, Y.J., Liu, B.Y., Ye, A.Z., and Yuan, H. (2012). A soil particle-size distribution dataset for regional land and climate modelling in China. Geoderma, 171, 85-91. https://doi.org/10.10 16/j.geoderma.2011.01.013

Whited, D.C., Kimball, J.S., Lorang, M.S., and Stanford, J.A. (2013). Estimation of juvenile salmon habitat in Pacific rim rivers using multiscalar remote sensing and geospatial analysis. River Res. Appl., 29(2), 135-148. https://doi.org/10.1002/rra.1585

Whittaker, R.H. (1960). Vegetation of the Siskiyou Mountains, Oregon and California. Ecol. Monogr., 30(3), 280-338. https://doi.

org/10.2307/1943563

Wohl, E. (2014). Time and the rivers flowing: Fluvial geomorphology since 1960. Geomorphology, 216(1), 263-282. https://doi. org/10.1016/j.geomorph.2014.04.012

Wu, W., Xu, Z.X., Yin, X.W., and Yu, S.Y. (2014). Fish community structure and the effect of environmental factors in the Wei river basin. Acta Scien. Circum., 34(5), 1298-1308. (in Chinese)

Xin, X., Huang, G., Liu, X., An, C., Yao, Y., Weger, H., Zhang, P., and Chen, X. (2017). Molecular toxicity of triclosan and carbamazepine to green algae chloro-coccum sp.: a single cell view using synchrotron-based fourier transform infrared spectromicroscopy. Environ. Pollut., 226, 12-20. http://doi.org/10.1016/j. envpol.201 7.04.007

Xin X.Y., Huang G.H., An C.J., Huang C., Weger H., Zhao S., Zhou Y., and Rosendahl S. (2018). Insights into the Toxicity of Triclosan to Green Microalga Chlorococcum sp. Using Synchrotron-Based Fourier Transform Infrared Spectromicroscopy: Biophysiological Analyses and Roles of Environmental Factors. Environ. Sci. Technol., 52, 2295-2306. http://org/doi/10.10121/acs.est.7b05533

Yu, L., Li, Y. P., Huang, G. H., and An, C. J. (2017). A robust flexible-probabilistic programming method for planning municipal energy system with considering peak-electricity price and electric vehicle. Energy Conversion Manage., 137, 97-112. https://doi.org/10.1 016/j.enconman.2017.01.028

Zanardo, S., Zaliapin, I., and Foufoula-Georgiou, E. (2013). Are American rivers Tokunaga self-similar? New results on fluvial network topology and its climatic dependence. J. Geophys. Res. (Earth Surf.), 118(1), 188-183. https://doi.org/10.1029/2012JF00 2392

Zeng, W.H., Zhang, Y.J., Liu, J.L., and Yang, Z.F. (2007). Web-based geographic information system for UWRSR evaluations. J. Environ. Inf., 10(2), 75-81. https://doi.org/10.3808/jei.200700102

Zhang, S.L., Yu, P.T., Zhang, H.J., Wang, Y.H., He, L.L., and Li, Z.H. (2015). A simulation study on the hydrological impacts of varying forest cover in the stony mountain area and loess area of the upper reaches of Jinghe Basin. Acta Ecol. Sin., 35(4), 1068-1078. (in Chinese)

Zhang, S.X., Guo, Y.K., and Wang, Z.W. (2015). Correlation between flood frequency and geomorphologic complexity of rivers network - A case study of Hangzhou China. J. Hydrol., 527, 113-118. https: //doi.org/10.1016/j.jhydrol.2015.04.060

Zhang, Y., Huang, G., An, C., Xin, X., Liu, X., Raman, M., Yao, Y. Wang, W., and Doble, M. (2017). Transport of anionic azo dyes from aqueous solution to gemini surfactant-modified wheat bran: synchrotron infrared, molecular interaction and adsorption studies. Sci. Total Environ., 595, 723-732. http://doi.org/10.1016/j.scitote nv.2017.04.031 